\title{
Universiteit
}

Leiden

The Netherlands

\section{IT and the judiciary in the Netherlands - A state of affairs}

Schmidt, A.H.J.

\section{Citation}

Schmidt, A. H. J. (2007). IT and the judiciary in the Netherlands - A state of affairs. Computer Law \& Security Report, 23(5), 453-460. Retrieved from https://hdl.handle.net/1887/12424

Version: $\quad$ Not Applicable (or Unknown)

License: $\quad$ Leiden University Non-exclusive license

Downloaded from: https://hdl.handle.net/1887/12424

Note: To cite this publication please use the final published version (if applicable). 


\title{
Technology and the Courts - Netherlands
}

\section{IT and the judiciary in the Netherlands - A state of affairs}

\author{
Aernout Schmidt \\ Professor of Law and ICT at Leiden University, Netherlands
}

\begin{abstract}
A B S T R A C T
If you have seen the movie 'The Servant', you may recognize the feeling. How a servant can invade her master's environment and gradually take control. The scenario is tightly connected with emotions: vulnerability of jurisdiction, abuse of culture, perverted reciprocity, lost autonomy and, finally, of decay. It takes little imagination to recognise the first signs of this scenario in a large number of IT-based environments, where service transforms itself from servant to master. Examples are abundant. My standard university work station has been configured to prevent me doing my work (researching the legal aspects of employing and deploying new information services). Inquiry consistently unearths argumentations of security and efficiency. With equal consistency, these argumentations refer to the service provider's security and efficiency, not those of the principal or the user. I wonder whether the 'Servant' comparison holds true for the judiciary and it's supporting computerization staff. That is the state of affairs referred to in the title of this article. The importance of the problems connected with it is too grave to put aside without further thought or reflection. I will first (i) give a short description of the recent organisational developments within the judiciary in the Netherlands, followed by (ii) a short survey of the currently available technology and (iii) an impression of things to come. From there (iv) I will deduce certain trends, and (v) analyse those trends in the light of the question how dependent the judiciary is becoming upon its information services. I will conclude that the reciprocities within and between the judiciary's sub-organisations represent great interest. An afterthought (vi) will conclude the paper and offer a few comparisons with Australia, the USA and the UK.
\end{abstract}

(C) 2007 Aernout Schmidt. Published by Elsevier Ltd. All rights reserved.

\section{Recent organizational developments}

Let me start off with a short outline of the organizational changes that resulted from the introduction of computerization in the judiciary in the recent past in the Netherlands. These events were set into motion during the 1990s. In this era it became apparent that the increasing administrative accountability of the Dutch Department of Justice led to an increasing pressure, urging to control expenditures and to evaluate their effectiveness. This movement yielded friction concerning the professional meaning of concepts such as 'judicial independency' and 'ministerial accountability'. The discussion focused on how organized supervision of expenditure and quality would affect the judge's constitutional independence. Discussions were held on administration and judicial interdependencies (Ingelse-Koers, 1998), on management and the value of a separate, professional organisation for the judiciary. Finance models were drafted, officials appointed, projects launched and recommendations commissioned. Budgets were outlined and laws were drafted (resulting in the 'Wet Raad voor de Rechtspraak' [Law on the Council of Justice] and the 'Wet organisatie bestuur gerechten' 
[Law on the Organisation of the Courts], both coming into force on 1 January 2002). As recommended by the seminal report 'Rechtspraak bij de tijd' ('Modern Administration of Justice') by a Commission presided by Leemhuis, in 1998 the creation of a 'Council of the Judiciary' was initiated which, after preparatory work, was officially launched on 1 January 2002. By design, the responsibility for the Project's Reinforcement Judicial Organisation (PVRO) was both allocated to the Council proper - which also assimilated the new IT organisational entities BISTRO (for Internet services) and IT Proeflakaal (for testing innovative services), or became a responsibility shared with the Public Prosecutor's Office (ICTRO).

After a period of organisational innovation (and the inevitable rattling of the cage of existing and customary management practices) a more clearly defined management structure for the Council of the Judiciary and its courts was established. It has become a dedicated legal Act: the 'Law on the Council of the Judiciary' which encompasses the revision of the traditional 'Law on the Judicial Organisation' (Wet RO).

Insofar as relevant for our subject, this Law states the following. The Council is entrusted with the support of the management of the courts and the supervision of the use of the courts' budgets. To carry out this task the Council is in particular concerned with, among other things, the computerization, the supply of management information and the quality of the administrative and managerial modus operandi of the courts. To fulfil these goals the Council can give general orders to the administrations of the courts, if management interests do so require. Before issuing such an order, the Council asks the Board of Representatives (comprising representatives from the courts) to voice its views. By ministerial implementing regulation, rules are set for financing the courts - in any case pertaining to objective measurement of workload and the way in which compliance with these rules in preceding periods will be taken into account when deciding on the budget. The Council is duty bound to provide the Minister with adequate information.

If the Law on the Council of the Judiciary accomplished anything at all, and it accomplished a lot, it is the clarification of the functional structures and administrative responsibilities within the judiciary - also in the field of IT-support. Just how far it leaves room for the Minister to influence the judiciary depends on the interpretation of the updated Wet RO and on the compliance practices to emerge.

\section{A short survey of available technology}

If one consults the literature on court technology, one will often find empirical statements describing the state of affairs in court technology, supplemented by opinions expressing either the superiority or antiquity of the use of IT in the courts (otherwise: Fabri and Langbroek, 2000). In the United States a bi-annual conference is held on the subject, frequented by a vast and diverse public of judges (often singing ICT-system praise), social scientists (attempting to describe how the legal organization employs IT), managers and economists (showing how efficiency can be improved) as well as computer scientists (eager to see their inventions being put to use). This biannual conference is useful, since new opportunities arise all the time and two year old knowledge of a descriptive ITrelated state of affairs is out-of-date almost instantly. Consequently, such descriptions are at considerable risk of being outdated even before they have made it to hardcopy. Nevertheless, a description - of the actual use of IT in the judiciary - is an essential and non-omissible part of this overview. Especially since it gives the current context of the development of the digitalization of the judiciary in the Netherlands, id est 2006. The direction and extent of that development have yet to emerge in practice.

Administrators and policymakers have very high expectations, even in a global sense. The World Bank, for instance has, for a considerable time now, been of the opinion that (i) the Rule of Law is a conditio sine qua non for a stable society and (ii) that the use of courtroom technology will support the establishment of the Rule of Law, even in the most unsavoury of jurisdictions (Carothers, 2003). From that perspective the assumption holds that computerization of the judiciary will contribute to an improvement in the quality of the adjudication of justice and thereby to an amelioration of unstable legal systems. In the Netherlands expectations of an improvement of quality are also held, as is evident from the efforts the Council of the Judiciary is making in the field of IT (see below). However, since the Netherlands already has a high quality judicial system compared with some jurisdictions that the World Bank is interested in, there is scope for the Netherlands to take a step backwards as well as one for the better. Does the use of IT in the judiciary actually lead to an improvement of the Rule of Law in the Netherlands (or influence it in any other way)?

IT-support can mean a great many things. It may, for instance, mean: the entire, complex, collection of IT-staff (information-analysts, programmers, helpdesk-employees, and system and network administrators), networks, computers and programs that as a whole support, and in ever increasing intensity even provide, the judiciary's information housekeeping. The virtual desktop (for the purposes of this paper) is defined as everything that goes on behind the screen of a judge's computer at the workplace. With IT in the judiciary I mean this virtual desktop.

The space reserved for this discourse permits me only to give a brief outline of the virtual desktop available to the Dutch judiciary in 2006. I have used among other (Dutch) sources the 'Informatiseringsplan 2005-2008 van de Raad voor de Rechtspraak' (ICT-blueprint of the Council for the Judiciary 2005-2008; an internal publication, the version of 6 January 2005) and, with his consent and an expression of my gratitude, the work of Ronald van den Hoogen, who is preparing a PhD thesis on the subject from the perspective of Art 6 of the European Convention on Human rights.

I will distinguish four separate characteristics of IT services. I assume that the way one appreciates any given instrument of the virtual desktop is related (i) to the character of that instrument (i.e., its specific combination of characteristics), (ii) to the expectations we hold of the instrument's functionality and (iii) to the extent in which we accept the policy that is implemented in or realised by that instrument. Every desktop instrument dictates. I understand the term 'policy' to denote legal, management or cultural rules that can be upheld with sanctions (like paper 
forms dictate policies, be it much more primitive than IT services tend to do).

Every instrument of the virtual desktop has four relevant characteristics (the following conceptualization is inspired by Douglas, 1970; Douglas and Wildavsky, 1982; Fodor, 1987; North, 1990). These characteristics combine to form the instrument's character. So here every IT instrument is assumed to have economic, administrative, individual and collective traits. Sometimes one of those traits is so dominates that it controls the instrument's character (or its implied policy). I will now give an overview of the different parts that make up the virtual desktop of the judiciary, sorted on its dominant trait.

First, the main quality of economic instruments is that they support the judiciary in achieving a higher efficiency. Computers were conjured up to be proficient at maths and mathematical programs have been a part of the desktop since the very beginning. As long as they save time and provide results that are backed by accepted models, they are acceptable. On the virtual desktop of the judiciary in the Netherlands I found the following programs to be of an economic nature: calculation of interest (mathematical program for the calculation of the legal interest due on a claim), alimony-indexation (mathematical program for the calculation of the indexation of an alimony obligation), cantonal judge's formula (used to compute the maintenance allowances after divorce, based on the so called cantonal judge's formula), and calculation of deadlines (used to compute whether certain legal terms will be or have been exceeded). I consider software for printing, sending e-mail, fax and IP-telephony to have a mainly economic character. They are all part of the standard working place, also for the Dutch judiciary.

Second, the foremost characteristic of an administrative instrument is that it supports its users to do their work within certain (legal and policy-related) constraints. Administrative instruments were developed in the wake of more economically oriented programs. As ever more economic instruments were being put to use in supporting transactions, the awareness grew that their use could be registered and processed in order to gain insights that could be used for policy making and enforcement. Potentially, every desktop application can generate data that can be used for administrative purposes. The level at which that actually happens determines the administrative emphasis of that instrument. The level of acceptance of the underlying distribution of competencies and the built-in 'policy', together with the level of privacy protection and the accuracy of the interpretation of the data, all play a role in the acceptability of the administrative aspect of the application. At the moment, the judiciary in the Netherlands is working with large national administrative and caseregistration systems of venerable age.

It has become customary to refer to those systems using acronyms. SAS, for 'Strafrecht Administratie Systeem' (Penal law Administration System), assists in the litigation of Penal cases. ARC (support for the magistrate, responsible for adequate police research) supports the administration of preliminary judicial research. NIAS (for New Appeal System) supports the administration of Penal cases in appeal and can visualize the completion times of those cases. 'Berber' supports the administrative adjudication and contains modules for administrative justice, for the adjudication of aliens, for tax law and for cases of the high administrative courts. Finally, this category also contains the Civil Law systems 'Civiel', 'NKP', 'Cirad/Rekest' and 'Bopzis'. These systems support private law adjudication, register the data of the plaintiffs, defendants and parties involved, the method of conclusion and the completion times. Security software is also part of such administrative instruments, for instance security-filters on Internet connections as well as auditing software to ensure the virtual desktop is not overloaded or corrupted and to track the cause of these problems should they occur. These instruments generally report to system administrators. An interesting case (in our context) has been the judge who collected child pornography on his desktop and got caught by the system administrator (and was later sentenced by his fellow judges).

Third, an individual instrument's most distinctive feature is that it allows customisation. They support - like a painter's palette - creative activities. Ease of use and reliability are the most important criteria, along with room for autonomy. Applications such as word processors and presentation software are prime instances. A nice example of progress in the Netherlands was the judiciary's migration from Microsoft Office 97 to Microsoft Office 2003 scheduled for 2006.

Fourth, Collective instruments are characterized by the bundling of powers through public or private networks with the aim of achieving collective goals most commonly related to the publication and dissemination of information. Search engines (Google, Yahoo) and Wikis exhibit this characteristic quite strongly. Collective instruments have only become widespread since the advent of the Internet and the World Wide Web (Google was established in 1998, Wikipedia in 2001). They have recently become available for projects, sometime after the computerization of the judiciary began in the Netherlands through the PVRO projects. Collective instruments have a hybrid nature: one can discern, in general terms, an editorial function, a contribution function and a users' function.

Collective instruments are acceptable if both contributors and users benefit from their use. Collective instrument are found in the field of ICTRO (the availability of search engines like Google through the virtual desktop) and, most notably in the field of BISTRO (e.g., the website 'Rechtspraak.nl', a public web-based information service which provides a great deal of information on the Dutch legal system to the public; Porta Iuris is the intranet portal of the judiciary itself, and as such is a collective instrument; Intro is the collective noun for the nationwide intranet and the local intranets of the judiciary). The goals of the intranet are improvement of internal communication, speeding up of information supply, improvement of administrative processes, improvement in keeping handbooks, guidelines, etc. kept up-to-date, increasing the accessibility of employees as well as access to central applications such as phonebooks, address books, etc.

\section{Services to come}

In 2002 the Council of Judiciary was apparently made responsible for a veritable bran tub of responsibilities with various 
incompatible and often outdated IT instruments. The Council perceives this to be a risk factor which has led to some commotion in the printed press which the Council voiced as 'Dependence on IT'. According to Rik Sanders, in Computable nr. 21, May 21, 2004 (p. 24) "stunning was the flop of the Administrative system for criminal cases in appeal (HBS) in 2001, costing around thirteen million Euros".

The subject has been dealt with, as far as one can tell, quite energetically and, with respect to its extent and level of complexity, quite effectively too. If all goes according to plan, the outdated systems will soon be replaced by more integrated systems: GPS (Integrated Process System) and REIS (Information System for the Judiciary). The construction and deployment of these services has fallen a little behind schedule, but in projects of this scale that is to be expected. Such projects require high demands of IT-governance in the abilities of the Council. More on that subject will be discussed later on.

In September 2003 the Project REIS started. Its goal is to build or reshape IT-systems for Civil and Administrative Law. The most important improvements are the use of digital 'dossiers' (filing), secure electronic messaging, integration (of record tables) and the support of archives within a digital environment. Besides REIS, work is also underway on the 'Basis Advocatenregistratie/Landelijk Advocatentableau' and on 'Financial Claims Online'. The Basic Advocatenregistratie contains information concerning lawyers and law offices. It is an initiative by the judiciary, the Dutch Order of Lawyers and the Council for Legal Aid. The 'Landelijk Advocatentableau' contains information that is of interest to the judiciary, such as: where payments are to be made and who are involved in supervising bankruptcies, etc. As a part of Rechtspraak.nl 'roljournaal' (the case-roll journal) is being developed. This free service allows lawyers that are listed in the 'tableau' to consult the actual court's case-roll through the Internet. The case-roll states who is authorized to take control of a certain case, a classification of pending cases, the names of plaintiffs and defendants, names of involved barristers and the current status of the case. 'Roljournaal' (Roll Journal) provides law offices with an overview of all the pending cases that their firm is involved in at a certain court and on a specific date. It also provides the firm with some search options, for instance searching on case number while allowing the history of the case to be viewed and providing an overview of all actions taken during the litigation process. It also allows the user to search for data regarding the involved parties. The system is meant to enhance efficiency within firms and at the court's registries. Digital access to the Roll should lead to the abandonment of Procurator services (required by local barristers for barristers from another courts' tableau, handling a case that will be decided in the Procurator's court) and should turn the electronic exchange of messages in Private Law cases finally into a reality (TK 2004-2005, 24 252, nr. 4).

The Integrated Penal Process System (GPS) will be the new process system for Penal cases at the courts, exchanging the paper dossier for an electronic version. A workflow management system fulfils the role of case manager in GPS. The workflow attempts to makes sure that all necessary actions during a process are taken in the right order and at the right time. After completing one action, the workflow system calculates which next step will be appropriate. This way, missing a deadline will be virtually impossible (that is: impossible by design) and the currently expanding numbers of formal errors are thus expected to diminish. Again, GPS is being developed in a multi-staged approach.

In both Civil and Administrative Law serious thought is given, in anticipation of REIS, to the possibilities for the electronic exchange of messages. The discussion in Administrative Law is closely linked to the Law on Electronic Administrative Transactions. However, the law does not pertain to the appeal before the administrative judge. The 'minutes of clarification' accompanying the Law expressly state that the electronic way of filing an appeal before the administrative judge should be in concordance with Civil and Penal Law. In everyday practice though, a lot of the communication between involved parties and the court is being conducted through electronic means. The minister of Justice is currently discussing with the Council of the Judiciary whether, how and under what conditions electronic communication with the courts should be made formal.

The judicial system as whole, of which the judiciary is but a part, also intends to use IT-applications for processing and presenting administrative and managerial information. In the infoRM program this is done on the basis of a datawarehouse concept. Management information is created on demand from the information in the warehouse, based on the criteria set by the user. The stated goal is to have the courts fulfil their information needs with ever less effort. But, comparison of the performance of the courts should also become easier. Let me translate from the 'Werkplan van de Raad voor 2006' mentioned before, p. 18: ...

The infoRM program aims to enhance management and strategic information in the adjudication of justice. 'Stuurhut' (Control cabin) and Datawarehouse are part of infoRM. Control cabin and Datawarehouse collect and present management information about the operation of the different process systems. In 2006, Control cabin will be completed and will have an interface with the Financial and HRM data of REIS and GPS... using a temporary solution and later through Datawarehouse. In order to govern reliability and timeliness of the information service we will begin to implement a dedicated controlling organization.

\section{Trends}

The development of the virtual desktop of the judiciary thus marks a revolution. Why? During the Industrial Revolution a general displeasure was felt because of the substitution of nature by machine, which led to a social revolution. Tonniës coined it the transition from Gemeinschaft to Gesellschaft. This process was fuelled by economic forces and has been accompanied by deep feelings of alienation. In 2006, in my opinion, something similar has happened. But this time it is not physical nature that is being tainted. This time it is literary culture that is being replaced by literary mechanics. As the flight of the agricultural worker to the factory sounded the start of a social revolution, so is it to be expected (if only on economic grounds) that the move of the individual professional to broader contexts, driven by the realisation of policies will 
leave social effects that have yet unknown outcomes and that are not readily welcomed by all.

The exhaustive list of diagnose-treatment combinations that recently made their entrance in the medical world in the Netherlands is a striking example. This list is implemented by means of IT and rules the practitioner's work (he/ she will not get paid for non-complying treatments). A similar development is underway in Dutch legal practice: lawyers flock to mega-firms and start using knowledge management systems in an organised manner. Cantonal courts have become an integral part of the regional courts, and the judiciary is struggling to maintain its independence under the Council of the Judiciary. Policies pop up everywhere. And those policies are perfectly suited for transfer to the virtual desktop. IT instruments can no longer be seen as simple instruments for individual support, but must also be understood as instruments for the realisation of certain policies, be it of general, administrative, security, cost or quality control in nature. In the preceding description of the virtual desktop of the judiciary tell-tale signs are present, indicating that this development is also taking place there: projects such as RechtspraaQ (introducing a quality management system) en the infoRM program, for instance. In my opinion this constitutes a trend: a trend that is fuelled by the powerful combination of administrative and collective qualities in desktop instruments. It forces organisations to search for new equilibriums. I will call this the new digital enforceability.

Where does it come from? In my opinion the foremost technical motive is that there is a growing realisation that collective and administrative instruments can be used to enhance each other's capabilities, together with the availability of an almost pervasive IT infrastructure. Let us look at Google to set an example. Google clearly is a mainly cooperative service. Google builds large searchable databases containing the contents and locations of Internet publications. Through Google, contributors and users of information form a global network with each other. But Google does more, it administrates: the company saves search queries and their source computer-addresses to process them administratively and create interest profiles of users. This allows Google to connect profiles with advertisements. Furthermore, Google's popularity allows it to create a lock-in situation. If you do not want to be profiled by Google you simply should not use Google; if you are dependent on the Internet, however, you have to take Google for granted and stop worrying about profiling. The latter choice is often preferred. This, in turn, leads to endless possibilities for administrative supervision. Google Netherlands (where it serves over $80 \%$ of all Internet searches) is without any doubt able to inform the Dutch authorities with details of a person's Internet use in cases where Google is obliged to do so under Dutch law.

This trend of new digital enforceability implies, mutatis mutandis, that the integrated virtual desktop of the judiciary will in future be in a position to report on the desktop use of the judges - if there was a legal obligation to do so. Further, at least in the Netherlands, since 1 January 2002 this is the case. The obligation can be read into the new Law RO. It is interesting to read that Law again, taking the emerging new digital enforceability into consideration. Let me repeat:
The Council is entrusted with the support of the management of the courts and the supervision of the use of the courts' budgets. To carry out this task the Council is in particular concerned with, among others, the computerization, the supply of management information and the quality of the administrative and managerial modus operandi of the courts (art 91 Wet RO). To fulfil these goals the Council can give general orders to the administrations of the courts, if management interests do so require. Before issuing such an order, the Council asks the Board of Representatives (comprised of representatives from the courts: art. $90 \mathrm{RO}$ ) to voice its views (art 92. RO). By ministerial implementing regulation, rules are set for financing the courts - in any case pertaining to objective measurement of workload and to the way in which compliance to these rules in preceding periods will be taken into account when deciding on the budget (art 94 RO). The Council is duty bound to provide the Minister with adequate information (art 105 RO).

All these tasks are better performed when improved administrative information services are available and when the information is not reliant on 'lock-in' as in the Google case, but can be enforced by the Council. These regulations can, furthermore, be embedded in the instruments of the virtual desktop, so there is little chance to avoid them. Judicial independence will obtain a whole new meaning when such instruments start taking off.

Let me slow down a bit. The virtual desktop of the judiciary in the Netherlands has not reached this stage yet. It is questionable whether the quality of the IT services in the judiciary is of such a standard, or that effective new forms of digital enforceability are presently at hand. Moreover, it is highly unlikely that the Minister of Justice and the Council of the Judiciary feel so responsible for (or have so little trust in) our judiciary that they would consider going to such lengths.

But still, it could happen. 9/11, Madrid and London have shed their incidental nature, partly because measures previously thought to be legally unsavoury suddenly have become en vogue, and have even received legal blessing. I'm referring, for instance, to the duty to keep logs on telecom traffic data, which has recently come into effect in the Netherlands and in Europe. Logs containing sender and recipient details are kept on all telephone and Internet traffic. This was formerly exclusively for the function of invoicing. Now the additional purpose is to facilitate the investigation of (the planning of) criminal acts.

The trend of growing digital enforceability makes this possible. I repeat that the feared situation is not at hand right yet, but that we should be aware of its possible emergence in the future.

That would, in my opinion, mean the following. When the time comes - and it will - a good reason will be presented for it just as, employing an analogy, in the 1980s there was good reason to prescribe hard penal sentencing guidelines in the USA. The USA sentencing practice had proved to be otherwise irreparably biased with the criminal's colour of skin. Supervision is not necessarily a bad thing, not even of the judiciary. But we should be wary, for risks concerning the quality of our Rule of Law are involved. Risks that directly and adversely affect the quality of our constitutional state. These issues should be given attention in advance. The key seems to be a revaluation 
of the normative orientation of the judiciary's organisation and the checks and balances that secure it into place. In the concluding section, then, I will turn my attention to this subject.

\section{Organisational fate}

Computerization does not unconditionally lead to progress. Spam, child porn, hacking, extremist digital communities, computer trespassing, misuse of facilities and the release of confidential information are all very common. Computerization is relatively new and is proliferating at an explosive speed. Societies are in transition - becoming information societies. Advice offered and decisions made by Government are dominated by technical and (often neo-classical) economic motives, hardly ever by legal insight. A scientific monograph titled 'Legal instruments, their development and the quality of the constitutional state' (paraphrasing North, 1990) is not to be expected anytime soon in the Netherlands. Why is it that the prominent position legal scholarship once held in judicial political decision making in the Netherlands has given way to economists, social scientists and computer scientists (e.g. Goudriaan, 2003; Dekker et al., 2004; van Velthoven, 2005)? Does that mean our normative Rule of Law is at risk of being replaced by some socio-economic Rule of Administration? What consequences arise for the computerization of the judiciary, and therefore for the judiciary itself? Can we learn something from the economists? And if jurisprudence is to play a stronger role, what should that be?

In 1937 Ronald Coase asked a similar question about economics to economists. He wondered how they could be so audacious as to give government advice based on assumptions (the existence of frictionless markets and omniscient parties) that were so blatantly flawed. To set an example, he investigated the puzzle why in practice it was sometimes more efficient to bundle forces into hierarchical organisations (firms) than to rely on the market for achieving that efficiency. Traditional assumptions in economics taught that allowing the market to do its work would lead to the highest efficiency. Practice showed otherwise. The cause of this discrepancy, according to Coase, lay in the costs involved in information gathering (related for instance to the process of figuring out which parties offer the highest returns versus the lowest values and costs) and in the costs of entering into spot contracts with those parties selected instead of a long term relationship (transaction costs). Those costs make it sometimes more efficient to organise some processes within firms than to let them happen on the free market.

Proceeding from this analytically based result it becomes possible to start working on explanations for the emergence and sustainability of organizations and on reasoning about their optimum size and their optimum level of specialisation also within the judiciary. After all, any organization comes at a certain cost too. Once these (marginal) costs outsize the benefit of reduced transaction costs, the organization's size has reached its rational limit.

In order to make claims on that subject, one needs to point out what the relevant internal structures of an organization are. In the current context an organization needs to have internal regulations (economists call them institutions) for defining internal, hierarchical relationships and those regulations need to be upheld. There also need to be external rules (contracts, general conditions) in order to create reliability for cooperation with external partners. And, finally, there needs to be some even more general (and effective) Rule of Law-like context, supporting a society where organizational transactions may flourish durably (see also Ellickson, 1991 and North, 1990).

Acceptance of internal and external rules of an organization means that parties who enter into contract with the organization give up some autonomy in exchange for certain benefits. Thus, the organisation of transactions can be analysed into collections of agency relationships in a trusted society - and individual agency relationships demand a minimal level of reciprocity for duration or sustainability. (Reciprocal agency relationships as fundamental to law and to economy, have a long-standing pedigree: i.e. Hobbes, 1651; Smith, 1776. They also emerge consistently in more recent game-theoretic models explaining cooperation.)

Looking from this perspective at the Council of the Judiciary, an organization makes reciprocity between the judiciary and the courts and between the courts and the Council a point of interest. This reciprocity can be articulated as the balance struck between the benefits the courts derive from working under the supervision of the Council and the disadvantages they experience from that system. In the Netherlands, opinions on these reciprocities can be communicated between the Council and the Board of Representatives, which is provided for by law (art $90 \mathrm{RO}$ ).

Inherent to hierarchical organisations is the fact that those who bear responsibility in the organisation should see their appointed tasks as the legitimisation of the internal rules they set and enforce. The very practice of rule promulgation and enforcement induces notions of sovereignty that, in the long run, need to be constrained. Jurisprudence has grown up with the constitutional "separation of powers" in order to curb excess. It is based on reciprocity. When we consider the organization of Council for the Judiciary, we have to keep this in mind.

Unlike businesses, the Council's goal is not profit but the realisation of quality adjudication practices. To achieve its goal, the Council can set rules. As has been said before, the increasing use of IT instruments on the virtual desktop generates more and more data to monitor the performance of individual judges, the resources they consult, the time they need to digest them, who they digitally confer with, and what digital dangers they run, etc. This growing abundance of digital data lowers the transaction costs of the Council's rule design, promulgation and enforcement efforts, since most of the data can be processed automatically (e.g., by means of workflow management and management information systems). Thus, there also exists economic appeal to growing digital enforceability in the judiciary. I would think that internal reciprocity - the perception of mutual benefit through internal transactions between judges, the courts and the Council - in the light of a durable judiciary should be the primary point of concern.

The preceding observations lead to the practical conclusion that - for the organization of the judiciary in the Netherlands - the (internal parliament-like) role of the Board of 
Representatives can hardly be overrated and probably deserves extra attention. Judging the wording of the executive ruling on the Board of Representatives, the legislator is aware of this important role (Kamerstukken II 1998/99, 26 352). A few citations from the Recitals introducing the Act read as follows:

- "The Board will monitor whether the Council respects the judicial independence;

- The Board's purpose is to ensure that, in the Courts, there remains durable support for the Council; and

- The Council will supply the Board with the information necessary for the realisation of its tasks."

Nevertheless, it is hard to find information on the actual performance of the Board. A short reference is made in the Council's strategic plan called the 'Agenda for justice 20052008 (Den Haag: July 2004)'. It states that the Board took part in a preparatory conference on 22 April 2004 and that a recommendation was given on the subject on 16 June of the same year. The Agenda was published in July. Apparently, drafting the Agenda in compliance with the Board's recommendations did not require much time.

\section{Afterthoughts}

First, it is appropriate to put the rhetorical comparison I made in the introduction into the right perspective. The suggestion that IT services are gaining power over the Dutch judiciary seems absurd, at least formally. The judges, the courts, the Council and the minister are still the ones responsible. This is true also for the IT services they deploy and use. Still, independence needs to be organized properly, especially where it clashes with considerations of economic efficiency and adequate specialization. Responsibility in the face of changing organization and specialization requires sensitive agency activities, that is, agency frameworks that do not make the independent responsibility of our judiciary 'leak away' to technicians and administrators who love policies but have no judicial responsibility at all.

Second, the relation between the responsible principal and IT service provider is notoriously difficult. The main reason is often found in the information asymmetry that is almost always present between principal (legal professional) and provider (computer scientist). This asymmetry makes it even harder than normal to judge reciprocities. The answer to questions about the organizational design of IT services for the judiciary is therefore hard to find. Three different scenarios have become common: (a) Application Service Providers (where the service is provided through networks and managed by the provider - an extreme form of outsourcing); (b) outsourcing of just the development and maintenance of the application while the administration is kept in-house; or (c) keeping the development and administration of applications entirely in-house (currently, the Dutch Council of the Judiciary carefully nurses in-house IT expertise). Whichever option is chosen, from experience it can be said that it is vital that the principal and the provider have knowledge of each other's role and are able to communicate at an adequate level. If that does not apply, we do run the risk that was pictured in the introduction: the expert dictates the conditions under which the layman uses the service.

Interestingly, parts of the American Sarbanes-Oxley Act (2002) address the problem, be it in a different context. It protects shareholder interests gained at the New York Stock Exchange by requiring to keep shareholders abreast of any company information pertaining to the stock value. This involves information system integrity. The Act makes the CEO and the CFO personally liable for the quality of the information processing involved. It has had great effect on ITgovernance practices in these firms. And somewhat more in context: IT-flops not only occur in Dutch Administrations; in the USA, for instance, an Act has been promulgated that is meant to prevent future IT disasters in Federal Administration: the Clinger-Cohen Act of 1996. Perhaps the Dutch legislator will find studying such legislation and their rationales beneficial.

Third, considering the IT-projects that our Council for the Judiciary has in operation currently, the state of affairs of IT and the Dutch Judiciary can be described as follows. There is a kaleidoscopic abundance of IT services available in the desktop, which is considered to demonstrate inadequate interoperability - mainly as a result of the fact that judiciary principals in IT-projects used to show themselves as 'islands of independence.' As from 1 January 2002, the Dutch Council for the Judiciary has been officially established, thus ending this organizational fragmentation. Its course is moving with the new digital enforceability trend as previously analyzed. It will presently result in the abundant availability of management data and, consequently, it will soon after raise new questions about organizational equilibriums within the Dutch Judiciary. Relevant rules concerning representing the individual courts are in place. There is little evidence, however, that the Board of Representative has already claimed its position of control. My conclusions are that with the introduction of the new enforceability into the Dutch organization of the udiciary, new equilibriums have to be found between the morals of the Law, of the Market and of IT-servicing and that finding these equilibriums has not yet shown in practice. Worse even, the articulation of adequate, updated conceptualizations and evaluation procedures seems to lag behind in the Netherlands.

Fourth, there might be interest in how the new enforceability, as described above, is faced in other countries. As I do not have the resources to investigate the issue in more depth, I venture an opinion based on sources made accessible through Symposium, 2004.

Let me first mention, however, that the new enforceability concerning the judiciary is a species of what Roger Clarke has coined "dataveillance" in his visionary article in 1988 (Clarke, 1988). In that paper he claims that surveillance is one of the elements of tyranny. What - at least to me - seems to get more than enough attention is the phenomenon of the concern expressed in Clarke, 1988. This follows the trend set by Huxley, 1932 and Orwell, 1949 in focusing on government surveillance of 'us, the people' and by subsequently entering the debate on privacy. Important as this may be, I have stressed something else here: the issue of the impact to be expected of digital surveillance capabilities of the government on our constitutionally grounded, institutionally independent 
judiciary. I do think we need to face the judiciary-independence interest now or at least soon. After all, we would hardly wish to be caught unawares by constitutional changes that have 'simply occurred' and lack deliberate and democratic legitimacy.

This type of concern is traditionally shared inside the USA (see: The Commission on Separation of Powers and Judicial Independence, 1997, and Symposium, 2006) as jurisdiction, responsibility and independence of government institutions are well-established core issues in the constitutional debate over there. However, the presidential initiatives concerning the War on Terror and Guantánamo Bay do currently claim priority over considerations about new enforceability and the judiciary. And rightly so, as the organizational position of Courtroom 21 shows that the efficiency of the judiciary is not governed by any central Administration in the USA.

Here I see a difference with European countries and Singapore, where the tendency is to centralize IT service provision for the courts. In the International Conference on the Legal and Policy Implications of Courtroom technology, held at Williamsburg on 13 February 2004, the contributions covered courtroom technology in the USA (Lederer, 2004; Wiggins, 2004), in Singapore (Magnus, 2004), in Australia (MacDonald and Wallace, 2004), in Canada (Borkowski, 2004), in the UK (Barnett, 2004; Brooke, 2004) and in Europe (Giuffrida, 2004) without a single one of the speakers even mentioning judicial independence and responsibility in relation to dataveillance as an issue deserving attention.

This bothers me. I do understand that efficiency and better co-ordination are worthy values. But so is judicial responsibility and independence. And I do know from earlier projects (e.g., Lodder et al., 2001) that major reorganizations of the European judiciaries have been going on, often resulting in intermediary institutions like the Dutch Council for the Judiciary. I am convinced that agencies will not only grab extra jurisdiction where they can, but also that they will eventually go on to abuse their power if countervailing institutions are not properly organised. After all, power corrupts - and let us not forget that to protect us against government corruption was the reason why we needed a responsible and independent judiciary in the first place.

Aernout Schmidt (a.h.j.schmidt@law.leidenuniv.nl) Professor of Law and ICT at Leiden University and Director of eLaw@Leiden, Centre for Law in the Information Society.

\section{REF E R E N C E S}

Barnett. The United Kingdom. Williams \& Mary Bill of Rights Journal 2004;12(3):687-98.

Borkowski Julian. Court technology in Canada. Williams \& Mary Bill of Rights Journal 2004;12(3):681-6.
Brooke Henry. The legal and the policy implications of courtroom technology: the emerging English experience. Williams \& Mary Bill of Rights Journal 2004;12(3):699-713.

Carothers Thomas. Promoting the rule of law abroad - the problem of knowledge, democracy and rule of law project: rule of law series number 34; January 2003.

Clarke Roger A. Information technology and dataveillance. Communications of the ACM May 1988;31(5):498-512.

Coase RH. The Nature of the firm. Economica, New Series November 1937;4(16):368-405.

Dekker Paul, et al. The level of trust in the judiciary [Vertrouwen in de Rechtspraak]. Den Haag: Sociaal Cultureel Planbureau; 2004.

Douglas Mary. Natural symbols. Random House; 1970.

Douglas Mary, Wildavsky Aaron. Risk and culture. University of California Press; 1982.

Ellickson R. Rules without law. Harvard University Press; 1991.

Fabri Marco, Langbroek Philip M. The challenge of change for judicial systems. Amsterdam: IOS Press; 2000.

Fodor JA. Psychosemantics. Cambridge, MA: The MIT Press; 1987.

Giuffrida Iria. Legal, practical and ethical implications of the use of technology in European courtrooms. Williams \& Mary Bill of Rights Journal 2004;12(3):745-68.

Goudriaan R. Adjudication of justice and productivity [Rechtspraak en productiviteit, een internationale verkenning]. Den Haag: APE; 2003;

Dekker Paul, et al. The level of trust in the judiciary [Vertrouwen in de Rechtspraak]. Den Haag: Sociaal Cultureel Planbureau; 2004.

Hobbes Thomas. Leviathan; 1651.

Huxley A. Brave new world. Harper \& Brothers; 1932.

Ingelse-Koers. A newspaper discussion in NRC - Handelsblad of February 7 and March 3; 1998 [in Dutch].

Lederer Frederic I. Introduction: what have we wrought? Williams \& Mary Bill of Rights Journal 2004;12(3):637-48.

Lodder Arno, Oskamp Anja, Schmidt Aernout. IT support of the judiciary in Europe. Sdu; 2001.

MacDonald, Wallace. Review of the extent of courtroom technology in Australia. Williams \& Mary Bill of Rights Journal 2004;12(3):649-59.

Magnus. The confluence of law and policy in leveraging technology: Singapore judiciary's experience. Williams \& Mary Bill of Rights Journal 2004;12(3):661-80.

North Douglass. Institutions, institutional change and economic performance. Cambridge University Press; 1990.

Orwell George. Nineteen eighty-four. Secker and Warburg; 1949.

Smith Adam. An inquiry into the nature and causes of the wealth of nations; 1776.

Symposium: international conference on the legal and policy implications of courtroom technology. Williams \& Mary Bill of Rights Journal 2004;12(3):637-872.

Symposium: emergency powers and the constitution. Georgia Law Review Spring 2006;40(3):699-914.

The Commission on Separation of Powers and Judicial Independence. An independent judiciary. American Bar Association; July 4, 1997.

Van Velthoven BCJ. The meaning of legal infra structure for the Dutch economy [De betekenis van de juridische infrastructuur voor de Nederlandse economie]. Den Haag: Raad voor de Rechtspraak; 2005 [Research Memoranda nr. 1-2005].

Wiggins Elizabeth C. What we know and what we need to know about the effects of courtroom technology. Williams \& Mary Bill of Rights Journal 2004;12(3):731-43. 